\title{
Issue of money laundering risks identification in the activity of the organizations and individual entrepreneurs engaged in the mining, production, use and circulation of precious metals and precious stones
}

\section{A. S. Vorobeva1, V. V. Zhdanovich², E. A. Kosova1, and P. Y. Leonov ${ }^{1}$}

${ }^{1}$ National Research Nuclear University MEPhl (Moscow Engineering Physics Institute), Kashirskoe shosse 31, Moscow, 115409, Russia

${ }^{2}$ Financial University under the Government of the Russian Federation 49 Leningradsky Prospekt, Moscow, Russia, 125993, GSP-3

\section{Abstract}

This article is distributed under the terms of the Creative Commons Attribution License,

Corresponding Author:

E. A. Kosova

e.kosova@hotmail.com

Received: 11 December 2017

Accepted: 20 January 2018

Published: 13 February 2018

Publishing services provided by Knowledge $\mathrm{E}$

(c) A. S. Vorobeva et al. This article is distributed under the terms of the Creative Commons

Attribution License, which permits unrestricted use and redistribution provided that the original author and source are credited.

Selection and Peer-review under the responsibility of the FinTech and RegTech: Possibilities, Threats and Risks of Financial Technologies Conference Committee.

\section{G OPEN ACCESS}

which permits unrestricted use and redistribution provided that the original author and source are credited.

Identification of money laundering risks in the sector of precious metals and precious stones is an important element in building an effective risk-based approach of money laundering risk assessment in the country. The article describes a mechanism of information exchange used in risk assessment of the organizations and individual entrepreneurs engaged in the mining, production, use and circulation of precious metals and precious stones. The mechanism is based on modern digital technologies such as a user's cabinet on the Federal financial monitoring service website. The risk-score is obtained as a result of the analysis of the information contained in the database of Rosfinmonitoring, as well as monitoring and oversight activities conducted by Federal state institution «The risk-score shall be provided to all subjects of the sector allowing them to quickly resolve the shortcomings in their activities.

Keywords: money laundering risk, sector of precious metals and precious stones, big data, information exchange, risk assessment, internal control.

\section{Introduction}

The sector of precious metals and precious stones brings together organizations working in the field of mining, production, use and circulation of precious metals and precious stones (Figure 1). 


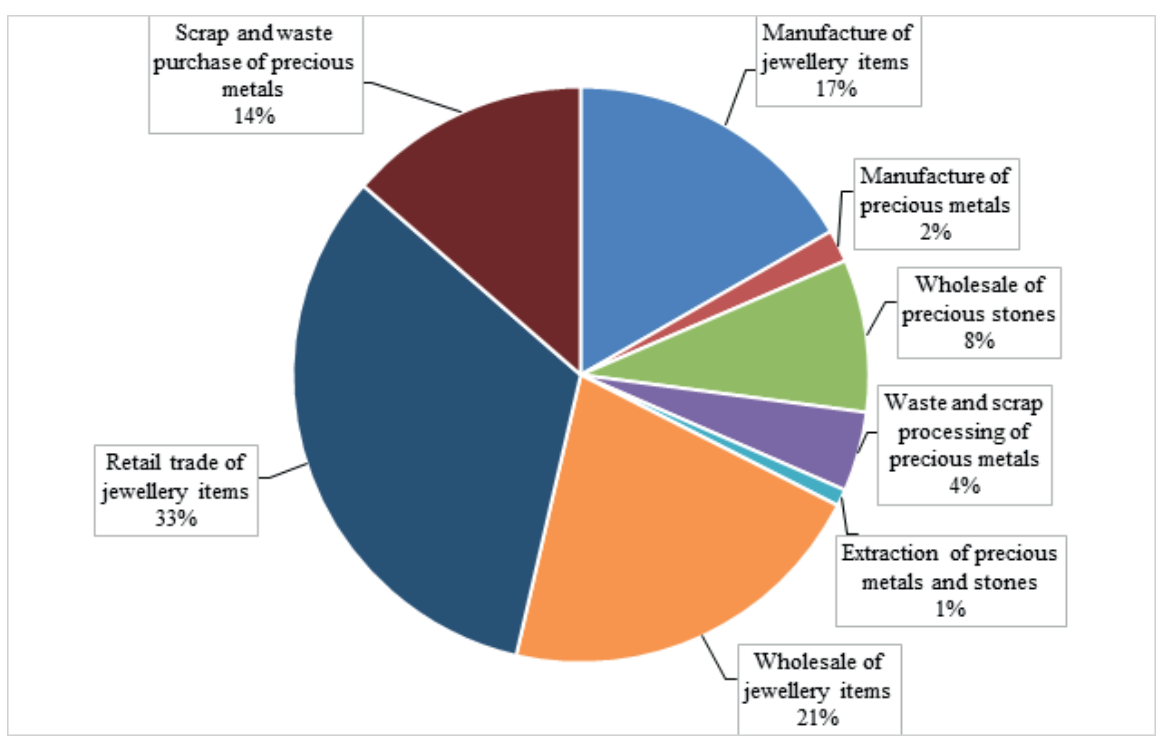

Figure 1: Main economic activities undertaken by the entities of the sector of precious metals and precious stones.

According to the Federal law «On combating legalisation (laundering) of proceeds from crime and financing of terrorism» No. 115-FZ [1] organisations involved in purchase, buy and sell of precious metals and precious stones, jewellery made out of them and scrap items are organizations performing operations with monetary funds or other assets. That is the reason they are obliged to meet the requirements of the abovementioned federal law. According to the legislation of the Russian Federation the Federal financial monitoring service (hereinafter Rosfinmonitoring) is an authorized body that within the framework of its powers [2] oversees operations (transactions) with monetary funds or other assets, as well as coordinates the activities of other state bodies and organizations in the area of combating money laundering and financing of terrorism including the sector of precious metals and precious stones. The state control and supervision in this sector is carried out by the Federal state institution «The Russian State Assay Office under the Ministry of Finance of the Russian Federation» (hereinafter FSI «Assay Office»).

At present, pursuant to the Decree of the Government of the Russian Federation No. 1052 [3] all organizations and individual entrepreneurs engaged in transactions with precious metals and precious stones required to be registered by FSI «Assay Office». In addition, certain categories of entities are subjected to licensing, in particular entities engaged in the extraction of precious metals, and refining enterprises can carry out its activities only if their inclusion in the list of authorized enterprises is defined by the Government of the Russian Federation. 
Modern digital technologies take place in the sector of precious metals and precious stones to simplify the process of state control. On the basis of the definition specified in the Strategy of the development of the information society in the Russian Federation for the 2017-2030 years [4], the digital economy is an activity where data in digital form is a key factor of production. The digital economy provides informational space tailored to needs of citizens and society in obtaining high quality and reliable information, develops the information infrastructure of the Russian Federation, contributes to creation and use of Russian information and telecommunication technologies, as well as the emergence of a new technological basis for the social and economic sphere. Thus, the key methods of the digital economy in the sphere of money laundering risk assessment are the formation of qualitative and reliable informational space including a big data technology. In accordance with the Program «Digital economy of the Russian Federation» [5], big data are the passing-through digital technologies that provide development of digital environment in general.

Rosfinmonitoring and FSI «Assay office» also apply the aforecited technologies. Over the past five years, the number of subjects registered in FSI «Assay Office» has exceeded 42000 legal entities and individual entrepreneurs. Similarly, the database of Rosfinmonitoring contains the information about organisations involved in the purchase, buy and sell of precious metals and precious stones, jewellery made out of them and scrap items. This information is an array of big data based on reports sent by the subjects of primary financial monitoring in the framework of internal (suspicious operations) and obligatory (operations above 6ook rubles) control through the user's cabinet on the Rosfinmonitoring Internet portal in accordance with the Regulation on the provision of information to the Federal financial monitoring service [6]. Thus, the user's cabinet of the organization is the main channel for information exchange between the subjects of the sector and the authorized body (Figure 2).

Based on the above-mentioned analysis of big data and the conducted monitoring and control activities by FSI «Assay Office», Rosfinmonitoring assesses the lawfulness of organizations using risk-based approach. The results of risk assessment are provided to the organizations through the user's cabinet and allow entities to correct the shortcomings in its system of internal control. Moreover, the results of risk assessment are taken into account by FSI «Assay Office» in carrying out regulatory activities. Based on the above, in the activities of the organizations and individual entrepreneurs engaged in the mining, production, use and circulation of precious metals and precious stones the following risk can be identified: low-level execution of anti-money laundering internal control system organization. 


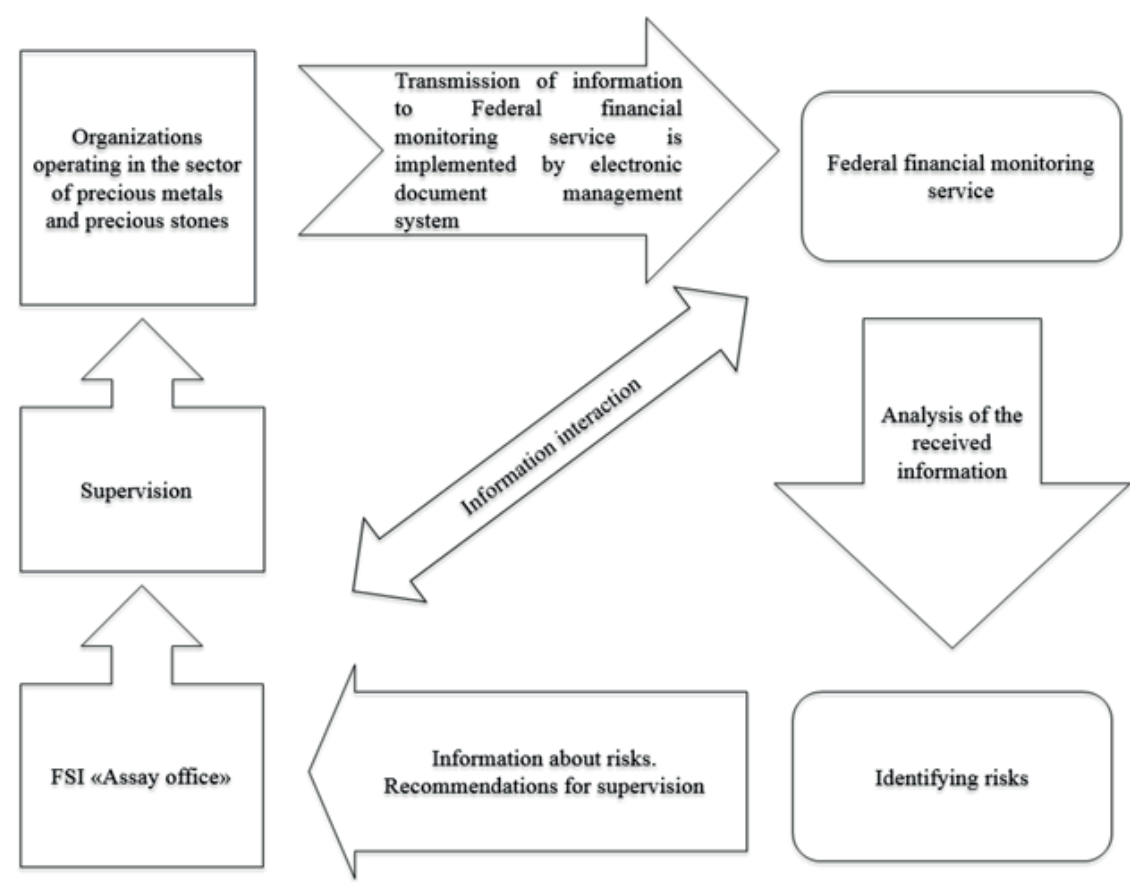

Figure 2: Information exchange mechanism.

However, it is worth noting that there are specific features in sector of precious metals and precious stones: most organizations engaged in retailing jewelry, are microand small enterprises, and therefore, their trading volumes are low. In addition, a large number of organizations operates in remote regions where the cost of jewelry does not exceed 40000 rubles, which leads to a slight flow of messages sent within the framework of the implementation of internal control measures.

In addition, it should be noted that there are more than 10 thousand organizations and individual entrepreneurs registered by FSI «Assay Office» who declared jewelry production as one of the economic activities. At the same time, there are more than 3.5 thousand registered brands of jewelry manufacturers and not all of them present jewelry for testing and branding. Thus, a significant proportion of the jewelry manufacturers does not actually carry out this activity.

Concerning money laundering carried out by the subjects of the sector of precious metals and precious stones, the following can be mentioned: the money laundering risks are often manifested directly in the last stage, according to the three-phase model of money laundering (placement, layering, integration) [7]. On the basis of the indicated model, investment of money occurs in the phase of integration, which entails investments of laundered money into the legitimate economy through acquiring different assets such as precious stones and expensive jewelry by the beneficiaries 
of criminal schemes. However, the percentage of organizations engaged in retailing of «premium» segment jewelry is fairly small, so the risks of unhindered usage of «shadow» schemes are practically non-existent.

Thus, it seems possible to argue that the risks of money laundering by the organizations and individual entrepreneurs engaged in the mining, production, use and circulation of precious metals and precious stones, are sufficiently low and manifested directly in the implementation of internal control measures by the subjects, as well as in the stage of integration of legalized proceeds into the legitimate economy.

\section{References}

[1] Federal Law of August 7, 2001 No. 115-FZ - «On Combating Legalisation (Laundering) of Proceeds from Crime and Financing of Terrorism» (ed. by 29.07.2017): [Electronic resource]/ConsultantPlus. 1997-2017. Electron. dataaccess mode: http://consultant.ru/document/cons_doc_LAW_32834 (date of circulation 06.11.2017).

[2] Matters concerning the Federal Financial Monitoring Service, approved by the Decree of the President of the Russian Federation from 13.06.2012 No 808 (ed. by 08.02.2016): [Electronic resource]/Federal financial monitoring service. 2001-2017. Electron. data access mode: http://fedsfm.ru/about/legal/752 (date of circulation 06.11.2017).

[3] The Decree of the Government of the Russian Federation from October 1, 2015 No. 1052 «On the conduct of the special accounting of legal entities and individual enterpreneurs, carrying out transactions with precious metals and precious stones»: [Electronic resource]/ConsultantPlus. 1997-2017. Electron. dataaccess mode: http://consultant.ru/document/cons_doc_LAW_186841 (date of circulation 06.11.2017).

[4] Strategy of information society development in the Russian Federation for 20172030 years, approved by the Decree of the President of the Russian Federation from 09.05.2017 No 203: [Electronic resource]/Office of the President of Russia year 2017. Electron. dataaccess mode: http://kremlin.ru/acts/bank/41919/page/1 (date of circulation 06.11.2017).

[5] Program of the digital economy of the Russian Federation, approved by the Decree of the Government of the Russian Federation from 28.07.2017 No 1632-p: [Electronic 
resource]/Analytical Centre of the Government of the Russian Federation. 19952017. Electron. data access mode: http://ac.gov.ru/files/content/14091/1632-rpdf.pdf (date of circulation 06.11.2017).

[6] Regulations on the provision of information to the Federal financial monitoring service by the organizations performing operations with monetary funds or other assets and individual entrepreneurs and the Federal service for financial monitoring requests to the organization, performing operations with monetary funds or other assets and individual entrepreneurs, approved by the Government of the Russian Federation from 19.03.2014 No 209 (ed. by 17.09.2016): [Electronic resource]/ConsultantPlus. 1997-2017. Electron. data access mode: http://consultant.ru/document/cons_doc_LAW_160535(date of circulation 08.11.2017).

[7] Zubkov V.A., Osipov, S.K., Russian Federation in the international system of counteraction to legalization (laundering) of criminal proceeds and terrorism financing. 2-nd Edition, revised and expanded.-M.: Publishing House "Gorodets", 2007.-752 p. 